\title{
Study on slagging characteristics and prevention of biomass briquette
}

\author{
Ren Xiaoping $^{* 1}$, Liu Fang ${ }^{2}$, Tang Xintong ${ }^{1}$, Yang jing ${ }^{1}$, Yang song ${ }^{1}$, Sun Xiaoting ${ }^{1}$ \\ ${ }^{1}$ Changchun Institute of Technology \\ ${ }^{2}$ Jiutai power plant of Huaneng Jilin Power Generation Co., Ltd, China
}

\begin{abstract}
It is a high efficiency, energy-saving and emission reduction measure to replace coal with biomass briquette fuel in a layer combustion furnace, but in the combustion process, the serious slagging problem has been restricted the promotion of biomass fuel. By analyzing the combustion characteristics of biomass briquette, the ash fusion characteristics and slagging mechanism, combined with the combustion characteristics of a layer combustion furnace, the important influence of key combustion parameters (furnace temperature, excess air, fuel layer thickness) on the slagging in the furnace is obtained, which provides a scientific basis for taking measures to prevent and control the slagging in the design and operation of the biomass briquette layer combustion furnace.
\end{abstract}

\section{Introduction}

China's annual biomass production is huge, and the amount of energy available is also considerable. For example, the annual output of agricultural straw biomass is equivalent to 308 million tons of standard coal. ${ }^{[1]} \mathrm{In}$ addition, biomass resources have the advantages of wide sources, easy access, renewable, less pollution and so on. But most of the straw is used as cooking fuel in rural areas with a low efficiency,or burned in the field, resulting in a great waste of energy.On the other hand,the large amount of coal is consumed with low thermal efficiency in the stoker,the serious environmental pollution problem also needs to be solved. ${ }^{[2]}$ It is an ideal choice to use crop straw instead of coal as the fuel of the stoker.The slagging problem of biomass fuel in stoker seriously affects the safety of boiler operation.

\section{Straw briquette and its combustion characteristics}

Using mechanical pressure molding technology, the loose straw, rice husk and other agricultural wastes with different particle sizes were compressed into a certain shape of dense straw briquette fuel.The pressed briquette is a kind of renewable energy,and has many advantages,such as high density, uniform particle size, high calorific value, low ash content, easy ignition and combustion,clean and low carbon. It has not only good combustion characteristics of straw, but also high calorific value and combustion resistance characteristics of coal.It can be used as boiler fuel instead of coal and applied in layer combustion furnace.The characteristics of several common biomass briquettes are shown in Table 1 .
The fixed carbon content of straw fuel is low, and the volatile content is high,so it is easy to ignite and burn. The whole process of straw combustion can be divided into three stages:evaporation, volatile emission and combustion,fixed carbon combustion and fuel burnout. In the initial stage of combustion, the volatile matter will be released at $250^{\circ} \mathrm{C}$, and $80 \%$ of the volatile can be released when the temperature reaches $350^{\circ} \mathrm{C}^{[3]}$. Because the release speed and combustion speed of volatile matter are very fast,it only accounts for about $10 \%$ of the whole combustion time.At this time, oxygen supply should be sufficient,otherwise, the loss of incomplete combustion of the atmosphere will be increased.The straw fuel is left with fixed carbon after losing volatile, and its structure is loose, and it is easy to form black flocs in the flue gas with the flow of flue gas,which results in incomplete combustion loss of solid.In the later stage of combustion, the fuel is less,the air volume is easy to excess,the combustion speed is slow and the smoke temperature decreases.

Table 1 Fuel characteristics of several biomass briquettes

\begin{tabular}{|c|c|c|c|}
\hline Types & Corn stalk & Wheat straw & Rice stem \\
\hline $\mathrm{C}_{\mathrm{ad}}(\%)$ & 38.92 & 40.68 & 35.14 \\
\hline $\mathrm{H}_{\mathrm{ad}}(\%)$ & 4.21 & 5.91 & 5.1 \\
\hline $\mathrm{O}_{\mathrm{ad}}(\%)$ & 40.26 & 35.05 & 33.95 \\
\hline $\mathrm{N}_{\mathrm{ad}}(\%)$ & 0.61 & 0.65 & 0.85 \\
\hline $\mathrm{S}_{\mathrm{ad}}(\%)$ & 0.23 & 0.18 & 0.11 \\
\hline $\mathrm{FC}_{\mathrm{ar}}(\%)$ & 19.24 & 25.67 & 13.95 \\
\hline $\mathrm{V}_{\mathrm{ar}}(\%)$ & 68.98 & 63.90 & 61.20 \\
\hline $\mathrm{M}_{\mathrm{ar}}(\%)$ & 5.26 & 7.31 & 12.2 \\
\hline $\mathrm{A}_{\mathrm{ar}}(\%)$ & 6.43 & 10.4 & 2.65 \\
\hline $\mathrm{Q}_{\mathrm{ar}, \mathrm{net}}(\mathrm{kJ} / \mathrm{kg})$ & 16120 & 15740 & 14654 \\
\hline
\end{tabular}


The density of straw briquette is generally $0.8-1.3 \mathrm{t} / \mathrm{m}^{3}$, which is much larger than the original straw, which greatly limits the release speed of volatile matter. In the early stage of combustion, the combustion is similar to "carbon particle combustion" $[4]$,and the combustion reaction is basically carried out on the fuel surface, so as to avoid the phenomenon of insufficient air supply and black smoke,and the loss of incomplete gas combustion is also small.After volatile emission and combustion,the dense carbon skeleton is left to continue combustion and release heat.It can be seen that the shape of the carbon block remains intact throughout the combustion process, the bright carbon block is wrapped by the surrounding bright yellow flame, the black flying catkins in the air flow are very few, the furnace temperature is significantly increased, and the firepower is long-lasting. The oxygen consumption in the combustion process is relatively stable with no high fluctuation.And then the combustion speed is relatively balanced,and the combustion state is stable.

\section{Slagging mechanism of straw briquette}

In addition to alkali metals such as potassium and sodium,straw itself is also rich in chlorine $(\mathrm{Cl})$. For biomass fuels with low chlorine content (such as wood), alkali metals are mainly precipitated in the form of sulfate and aluminum silicate during combustion.But in respect of the biomass fuels with high chlorine content (such as straw and grass), alkali metals are mainly precipitated in the form of gaseous chloride. With the increase of temperature, the content of potassium and chlorine decreases. Between $600^{\circ} \mathrm{C}$ and $800^{\circ} \mathrm{C}$, a large amount of chlorine is lost,and the content in ash is basically zero in $800^{\circ} \mathrm{C}$, forming gaseous products of sodium chloride $(\mathrm{NaCl})$ and potassium chloride $(\mathrm{KCl})$. Their melting points are $801^{\circ} \mathrm{C}$ and $770^{\circ} \mathrm{C}$ respectively. The potassium content in crop straw is much higher than that in sodium,so the production of potassium chloride $(\mathrm{KCl})$ is much higher than that of sodium chloride $(\mathrm{NaCl})$.

During the straw combustion, these alkali metal sulfates,chlorides and silicates become the state of gas phase and condense on the surface of ash particles, which reduces the melting point of the fly ash,increases the viscosity of the fly ash and intensifies the slagging of ash.

\section{Melting characteristics of straw ash}

The ash composition can be used to accurately evaluate the fusion characteristics of fuel ash,and the slagging tendency can be judged according to the content of alkali metal oxides such as potassium and sodium in the ash.The composition of common biomass ash is shown in Table 2,the melting temperature of common pure oxides is shown in Table $3^{[5,6]}$. Generally, $\mathrm{Al}_{2} \mathrm{O}_{3}$ and $\mathrm{SiO}_{2}$ play a role in increasing ash melting point, while $\mathrm{K}_{2} \mathrm{O}, \mathrm{Na}_{2} \mathrm{O}$ and $\mathrm{Fe}_{2} \mathrm{O}_{3}$ are fusible components, and the higher the content of these components, the lower the ash melting point. When the ratio of $\mathrm{SiO}_{2}$ content to $\mathrm{Al}_{2} \mathrm{O}_{3}$ content is greater than 1.18, free $\mathrm{SiO}_{2}$ is easy to form eutectic with $\mathrm{CaO}, \mathrm{MgO}$ and $\mathrm{FeO}$. The melting point of these eutectic is lower,which reduces the ash melting temperature and enhances the ash slagging tendency.Generally,the melting point of the same kind of ash will decrease in reducing atmosphere, but it is higher in oxidizing atmosphere.

Table 2 Composition analysis of several biomass ashes

\begin{tabular}{|c|c|c|c|}
\hline Types & Corn talk & Wheat straw & Rice stem \\
\hline $\mathrm{K}_{2} \mathrm{O}$ & 5.41 & 26.6 & 13.3 \\
\hline $\mathrm{Na}_{2} \mathrm{O}$ & 1.29 & 2.71 & 0.96 \\
\hline $\mathrm{Al}_{2} \mathrm{O}_{3}$ & 4.3 & 1.88 & 2.04 \\
\hline $\mathrm{Fe}_{2} \mathrm{O}_{3}$ & 4.69 & 1.73 & 0.85 \\
\hline $\mathrm{CaO}$ & 5.15 & 7.14 & 3.01 \\
\hline $\mathrm{MgO}$ & 3.92 & 2.06 & 1.75 \\
\hline $\mathrm{TiO}_{2}$ & 0.22 & 0.08 & 0.09 \\
\hline $\mathrm{SiO}_{2}$ & 73.2 & 56.32 & 74.67 \\
\hline $\mathrm{P}_{2} \mathrm{O}_{5}$ & 1.05 & 1.26 & 2.41 \\
\hline
\end{tabular}

\section{Influence factors of the slagging}

The slagging on a heating surface is a common problem when straw briquette is burned in layer combustion furnace, which seriously affects the safe and economic operation of boiler and limits the popularization of straw briquette. Taking corn straw briquette as an example, the particle size of briquette is $110 \mathrm{~mm}$ round rod, the density is $1.1 \mathrm{t} / \mathrm{m}^{3}$, the moisture content is $12 \%$, and the low heat value of as received basis is $16538 \mathrm{~kJ} / \mathrm{kg}$. It is found that the slagging of heating surface is closely related to the combustion conditions in the furnace.

\subsection{The influence of temperature}

Temperature directly affects slag formation, and high temperature has been proved to be one of the most important reasons for slag formation. The higher the general temperature, the more obvious the trend of slag formation, and the larger the size of the slag block. At higher temperature, the release of sodium,potassium and chlorine in fuel ash will lead to the rapid slag formation on the heating surface. ${ }^{[7]}$ The relationship between slag formation rate and furnace outlet temperature is shown in the Fig. 1 .

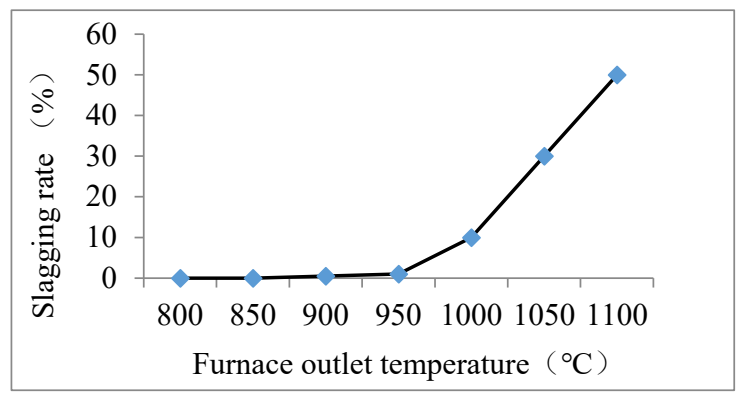

Fig. 1 Relationship between slagging rate and furnace outlet temperature 
It can be seen from Figure 1 that when the furnace outlet temperature is lower than $950^{\circ} \mathrm{C}$, the slagging rate is very low,which indicates that the slagging phenomenon is not easy to occur on the heating surface. When the furnace temperature is higher than $950^{\circ} \mathrm{C}$, the slagging rate increases rapidly with the increase of furnace outlet temperature.

\subsection{Influence of fuel layer thickness}

Under the best combustion condition, combustion tests are carried out for different fuel layer thickness ${ }^{[8]}$, and the relationship between the slagging rate and the fuel layer thickness is obtained,as shown in Fig.2.

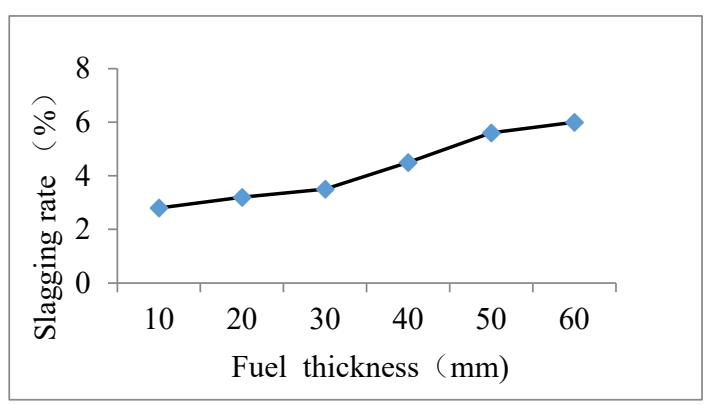

Fig.2 Relationship between slagging rate and fuel thickness

It can be seen from Figure 2 that the slagging rate increases with the increase of fuel layer thickness. The reason is that the thickness of the reduction layer in the combustion layer increases with the increase of the thickness of fuel layer.So that the reducing atmosphere increases. The temperature of the combustion center increases with the increase of the fuel thickness,so the ash is easier to reach the ash melting point,resulting in the increase of the slagging rate.

\subsection{The influence of excess air on the coefficient}

The relationship between slagging rate and excess air coefficient is shown in Fig.3.

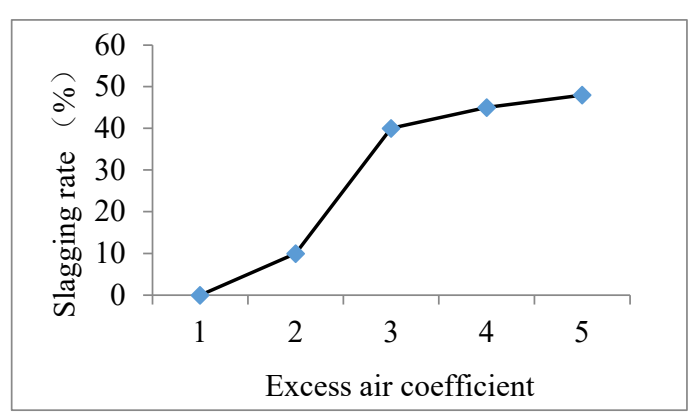

Fig. 3 Relationship between slagging rate and excess air coefficient

It can be seen from the figure 3 that when the excess air coefficient is less than 1.25 , the slagging rate is very low. When the excess air coefficient is $1.25 \sim 1.5$,the slagging rate increases slowly with the increase of excess air coefficient. When the excess air coefficient is greater than 1.5 ,the slagging rate increases sharply with the increase of excess air coefficient. When the excess air coefficient is greater than 3, the slagging rate flatly increases with the increase of excess air coefficient.

\section{Slag prevention and reduction measures}

According to the ash content and its melting characteristics,as well as the factors affecting ash slagging,combined with the combustion characteristics of the layer combustion furnace,the related measures should be taken to reduce the slagging problem in the design and operation of the layer combustion furnace burning corn straw shaped fuel.

\subsection{Control furnace outlet temperature}

During the design and operation, the flue gas temperature at the furnace outlet should be controlled below $800^{\circ} \mathrm{C}$, which can effectively reduce the formation of the low melting point alkali metal sulfate and other substances, so as to reduce the tendency of slagging on the heating surface.

\subsection{Reasonable excess air}

In the design and operation,the excess air coefficient at the furnace outlet should be controlled at about 1.2,and the maximum should not exceed 1.5.If the air quantity is too low,incomplete combustion of the fuel is easy to occur.If the air quantity is too high, it will not only be unfavorable to the fuel combustion, but also aggravate the slagging on the heating surface.

\subsection{Reasonable fuel layer thickness}

For the corn straw briquette with particle size of $80 \sim 120 \mathrm{~mm}$, the thickness of fuel layer should be controlled about $50 \mathrm{~mm}$. With the increase of fuel layer thickness,not only the slagging rate,but also the incomplete combustion loss will increase.

\section{7 summary}

Because of the growth demand,the straw itself is rich in alkali metals and chlorine elements such as potassium and sodium,which causes the ash melting point to be low, and it is easy to form slag on the heating surface when burning in the boiler.It is found that the slagging rate of straw shaped fuel in the laminar combustion furnace will increase to some extent with the increase of temperature,excess air coefficient and fuel layer thickness.It is true that the corresponding measures, as mentioned above,can effectively reduce slag formation and realize safe and economic combustion,which provides the scientific basis for the design and operation of the layer combustion furnace burning straw shaped fuel. 


\section{References}

1. Zhang yi, Study on the mechanism and control technology of biomass briquette slagging, North China University of Technology, (2017)

2. Xia xuning, Experimental study on slagging characteristics of biomass briquette fuel chain boiler, Henan agricultural university, (2016)

3. Bi Huijie, Wu Yingwei, Huang Zhi, Discussion on the conversion of coal-fired boiler to biomass pellet fuel, District heating, No.6(2012)

4. Yan Weiping, Chen Yinling, Analysis and discrimination of slagging characteristics of biomass fuel, Journal of North China Electric Power University,Vol.34,No.1,49-53(2007)

5. Liu Shengyong, Li Wenya, Experimental study on slagging characteristics of biomass briquette combustion equipment, Journal of agricultural engineering, 135-137, Oct.(2006)

6. Wang huaidong, Wang Xiaodong, Experimental study on slagging characteristics and influencing factors of biomass briquette stoves, Journal of Hebei Agricultural University, 206-209,(2018)

7. Ma Xiaoqin, Li Gang, Analysis on the prospect of transforming small coal-fired boiler into straw briquette boiler, Rural energy, issue 5 (total issue 99),(2010) 